Prepared in cooperation with the South Carolina Department of Health and Environmental Control

\title{
Tritium Concentrations in Environmental Samples and Transpiration Rates from the Vicinity of Mary's Branch Creek and Background Areas, Barnwell, South Carolina, 2007-2009
}

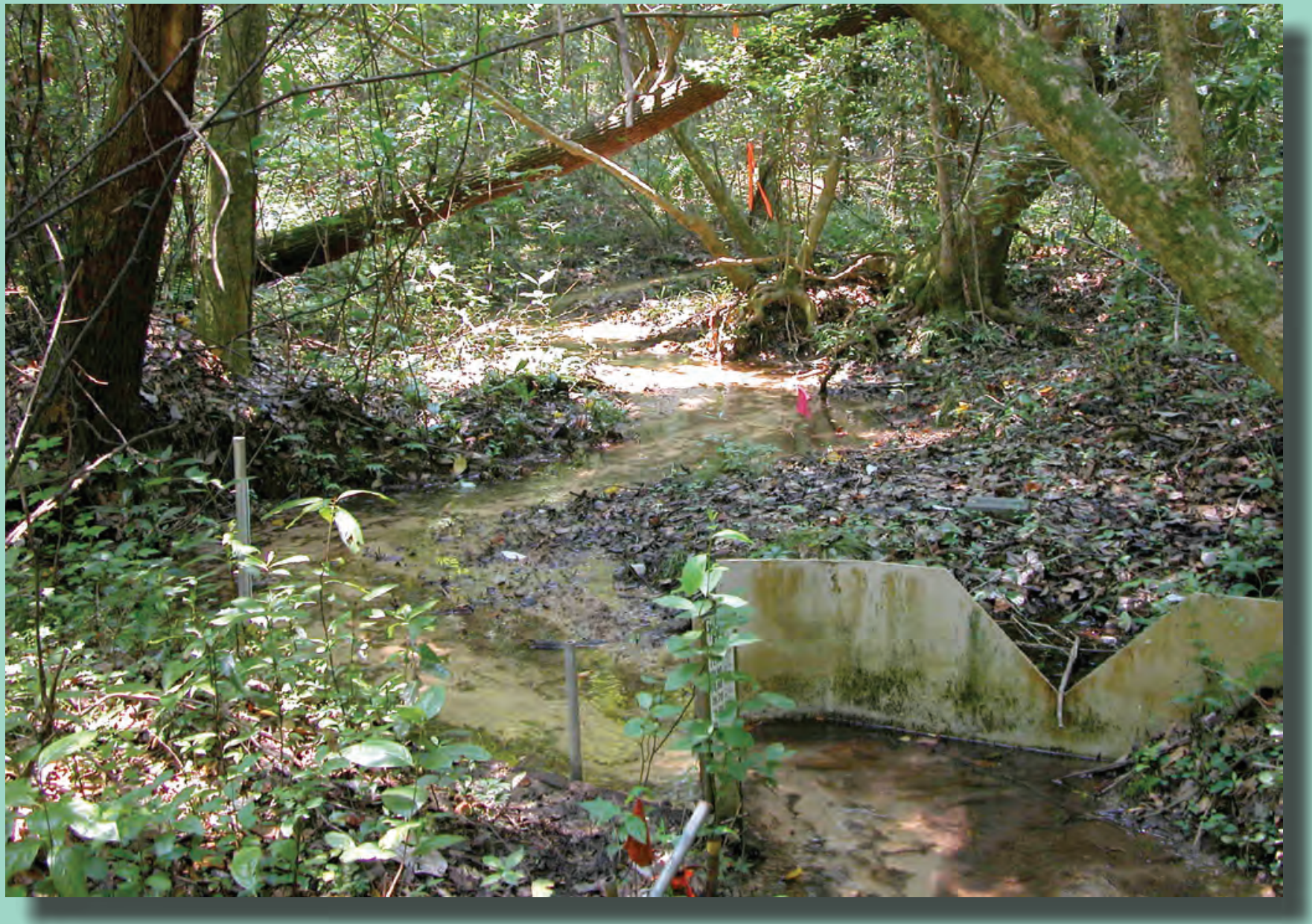

Scientific Investigations Report 2009-5245 
Cover. Mary's Branch Creek near tree T16 looking southwest, Barnwell, South Carolina, June 29, 2009 (photograph by Don A. Vroblesky, U.S. Geological Survey). 


\section{Tritium Concentrations in Environmental Samples and Transpiration Rates from the Vicinity of Mary's Branch Creek and Background Areas, Barnwell, South Carolina, 2007-2009}

By Don A. Vroblesky, Judy L. Canova, Paul M. Bradley, and James E. Landmeyer

Prepared in cooperation with the South Carolina Department of Health and Environmental Control

Scientific Investigations Report 2009-5245 


\title{
U.S. Department of the Interior \\ KEN SALAZAR, Secretary \\ U.S. Geological Survey \\ Marcia K. McNutt, Director
}

\section{U.S. Geological Survey, Reston, Virginia: 2009}

\author{
For more information on the USGS — the Federal source for science about the Earth, its natural and living resources, \\ natural hazards, and the environment, visit http://www.usgs.gov or call 1-888-ASK-USGS \\ For an overview of USGS information products, including maps, imagery, and publications, \\ visit http://www.usgs.gov/pubprod \\ To order this and other USGS information products, visit http://store.usgs.gov
}

Any use of trade, product, or firm names is for descriptive purposes only and does not imply endorsement by the U.S. Government.

Although this report is in the public domain, permission must be secured from the individual copyright owners to reproduce any copyrighted materials contained within this report.

Suggested citation:

Vroblesky, D.A., Canova, J.L., Bradley, P.M., and Landmeyer, J.E., 2009, Tritium concentrations in environmental samples and transpiration rates from the vicinity of Mary's Branch Creek and background areas, Barnwell, South Carolina, 2007-2009: U.S. Geological Survey Scientific Investigations Report 2009-5245, 12 p. 


\section{Contents}

Abstract

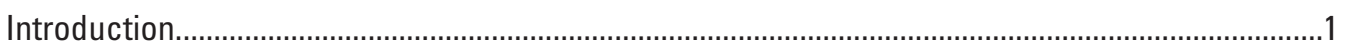

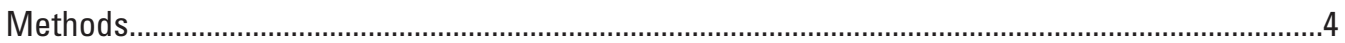

Tritium Concentrations in Environmental Samples …………........................................................

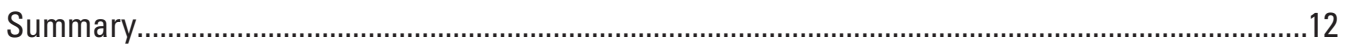

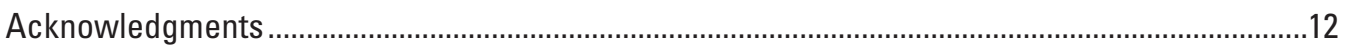

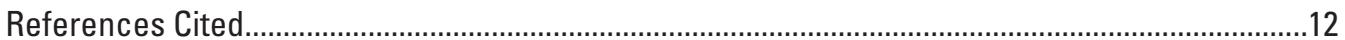

\section{Figures}

1. Map showing the location of Barnwell Disposal Facility and concentrations of tritium in groundwater, Barnwell, South Carolina ........................................................2

2. Map showing sampling locations near Mary's Branch Creek, Barnwell, South Carolina, 2007-2009

3-5. Photographs showing -

3. Mary's Branch Creek showing tree T27, looking northwest, Barnwell, South Carolina, June 29, 2009 .

4. Vial containing tree core and plastic screen to isolate wood from extracted water.

5. Frozen water bottle, funnel, and 40-milliliter vial in the process of condensing water from forest air near Mary's Branch Creek, Barnwell, South Carolina, June 8, 2009

6. Graph showing sap-flow measurements from tree T14, October 2, 2008, near Mary's Branch Creek, Barnwell, South Carolina..........................................................11

7. Conceptualization of water movement in the forest near Mary's Branch Creek, Barnwell, South Carolina

\section{Tables}

1. Trees sampled near Mary's Branch Creek and in background areas, Barnwell, South Carolina, 2007-2009.

2. Concentrations of tritium in groundwater near Mary's Branch Creek and in surface water from Mary's Branch Creek, Barnwell, South Carolina, 2008-2009.

3. Concentrations of tritium in water extracted from tree cores near Mary's Branch Creek, Barnwell, South Carolina, and from background areas, 2008-2009

4. Concentrations of tritium in whole tree cores near Mary's Branch Creek, Barnwell, South Carolina, and from background areas, 2007-2008

5. Concentrations of tritium in water condensed from air and concentrations of tritium in air near Mary's Branch Creek, Barnwell, South Carolina, and from background areas, 2008-2009

6. Transpiration rates measured in trees at Mary's Branch Creek, Barnwell, South Carolina, 2008-2009. 


\section{Conversion Factors}

\begin{tabular}{lcl} 
Inch/Pound to SI & & \\
\hline \multicolumn{1}{c}{ Multiply } & By & \multicolumn{1}{c}{ To obtain } \\
\hline & Length & \\
inch (in.) & 2.54 & centimeter $(\mathrm{cm})$ \\
inch (in.) & 25.4 & millimeter $(\mathrm{mm})$ \\
foot (ft) & 0.3048 & meter $(\mathrm{m})$ \\
mile (mi) & 1.609 & kilometer $(\mathrm{km})$ \\
& Area & \\
acre & 4,047 & square meter $\left(\mathrm{mt}^{2}\right)$ \\
square foot $\left(\mathrm{ft}^{2}\right)$ & 0.09290 & square meter $\left(\mathrm{mt}^{2}\right)$ \\
square mile $\left(\mathrm{mi}^{2}\right)$ & 2.590 & square kilometer $\left(\mathrm{km}^{2}\right)$ \\
& Volume & \\
gallon (gal) & 3.785 & liter $(\mathrm{L})$ \\
\hline
\end{tabular}

\begin{tabular}{|c|c|c|}
\hline Multiply & By & To obtain \\
\hline \multicolumn{3}{|c|}{ Length } \\
\hline centimeter $(\mathrm{cm})$ & 0.3937 & inch (in.) \\
\hline millimeter $(\mathrm{mm})$ & 0.03937 & inch (in.) \\
\hline $\operatorname{meter}(\mathrm{m})$ & 3.281 & foot $(\mathrm{ft})$ \\
\hline kilometer $(\mathrm{km})$ & 0.6214 & mile (mi) \\
\hline \multicolumn{3}{|c|}{ Area } \\
\hline square meter $\left(\mathrm{m}^{2}\right)$ & 10.76 & square foot $\left(\mathrm{ft}^{2}\right)$ \\
\hline square kilometer $\left(\mathrm{km}^{2}\right)$ & 0.3861 & square mile $\left(\mathrm{mi}^{2}\right)$ \\
\hline \multicolumn{3}{|c|}{ Volume } \\
\hline liter $(\mathrm{L})$ & 1.057 & quart (qt) \\
\hline liter (L) & 0.2642 & gallon (gal) \\
\hline cubic meter $\left(\mathrm{m}^{3}\right)$ & 35.31 & cubic foot $\left(\mathrm{ft}^{3}\right)$ \\
\hline \multicolumn{3}{|c|}{ Pressure } \\
\hline kilopascal $(\mathrm{kPa})$ & 20.88 & pound per square foot $\left(\mathrm{lb} / \mathrm{ft}^{2}\right)$ \\
\hline \multicolumn{3}{|c|}{ Density } \\
\hline kilogram per cubic meter $\left(\mathrm{kg} / \mathrm{m}^{3}\right)$ & 0.06242 & pound per cubic foot $\left(\mathrm{lb} / \mathrm{ft}^{3}\right)$ \\
\hline
\end{tabular}

Temperature in degrees Celsius $\left({ }^{\circ} \mathrm{C}\right)$ may be converted to degrees Fahrenheit $\left({ }^{\circ} \mathrm{F}\right)$ as follows:

$$
{ }^{\circ} \mathrm{F}=\left(1.8 \times{ }^{\circ} \mathrm{C}\right)+32
$$

Abbreviations used in this report

$\begin{array}{ll}A H & \text { absolute humidity } \\ A V P & \text { absolute vapor pressure } \\ \text { BLS } & \text { below land surface } \\ C_{A} & \text { concentration of tritium in air } \\ C_{W} & \text { concentration of tritium in water } \\ \text { DPM } & \text { disintegrations per minute } \\ \text { DPM/tree } & \text { disintegrations per minute per tree core } \\ \text { pCi/L } & \text { picocuries per liter } \\ R H & \text { relative humidity } \\ \text { SVP } & \text { saturation vapor pressure } \\ \text { USGS } & \text { U.S. Geological Survey }\end{array}$




\title{
Tritium Concentrations in Environmental Samples and Transpiration Rates from the Vicinity of Mary's Branch Creek and Background Areas, Barnwell, South Carolina, 2007-2009
}

\author{
By Don A. Vroblesky', Judy L. Canova ${ }^{2}$, Paul M. Bradley', and James E. Landmeyer ${ }^{1}$
}

\section{Abstract}

Tritium in groundwater from a low-level radioactive waste disposal facility near Barnwell, South Carolina, is discharging to Mary's Branch Creek. The U.S. Geological Survey conducted an investigation from 2007 to 2009 to examine the tritium concentration in trees and air samples near the creek and in background areas, in groundwater near the creek, and in surface water from the creek. Tritium was found in trees near the creek, but not in trees from background areas or from sites unlikely to be in direct root contact with tritium-contaminated groundwater. Tritium was found in groundwater near the creek and in the surface water of the creek. Analysis of tree material has the potential to be a useful tool in locating shallow tritium-contaminated groundwater. A tritium concentration of 1.4 million picocuries per liter was measured in shallow groundwater collected near a tulip poplar located in an area of tritium-contaminated groundwater discharge. Evapotranspiration rates from the tree and tritium concentrations in water extracted from tree cores indicate that during the summer, this tulip poplar may remove more than 17.1 million picocuries of tritium per day from the groundwater that otherwise would discharge to Mary's Branch Creek. Analysis of air samples near the tree showed no evidence that the transpirative release of tritium to the air created a vapor hazard in the forest.

\section{Introduction}

The Barnwell Disposal Facility is near Barnwell, South Carolina, and has been accepting low-level radioactive waste for burial since 1971. The facility is about 5 miles west of Barnwell, South Carolina, and includes approximately 235 acres (fig. 1). Tritium contamination from the facility is present in groundwater in a plume that extends from the

${ }^{1}$ U.S. Geological Survey, Columbia, South Carolina.

${ }^{2}$ South Carolina Department of Health and Environmental Control, Columbia, South Carolina. facility southwestward to Mary's Branch Creek (fig. 1; Energy Solutions, 2007). Overland flow and most precipitation that enters the groundwater system at the disposal facility drains to Mary's Branch Creek, approximately 3,000 feet (ft) south of the disposal facility (Cahill, 1982). Mary's Branch Creek is predominantly a groundwater-supplied water body, originating as seeps, some of which are in the discharge area for groundwater affected by the Barnwell Disposal Facility. The presence of tritium in surface water at Mary's Branch Creek in the area of investigation $(175,000$ to 515,000 picocuries per liter $[\mathrm{pCi} / \mathrm{L}])$ and in groundwater beneath and near the creek $(1,100,000 \mathrm{pCi} / \mathrm{L})$ indicates that tritium-contaminated groundwater discharges to Mary's Branch Creek (Energy Solutions, 2007). The area of probable tritium-contaminated groundwater discharge to Mary's Branch Creek is the study area for this investigation (figs. 1 and 2).

The area around Mary's Branch Creek is a forest (fig. 3), consisting primarily of tulip poplar (Liriodendron tulipifera), oak (Quercus sp.), sweet gum (Liquidambar sp.), and holly (Ilex sp.). Less common species include loblolly pine (Pinus taeda) and sweet bay (Laurus nobilis). Utilization of soil water by the trees and evaporation reduces the amount of groundwater discharging to the creek. The reduction of groundwater discharge by trees and evaporation is confirmed by the observation that although the highest rainfall occurs during the summer months, the highest streamflow occurs during the winter months (Cahill, 1982). Mary's Branch Creek discharges into Lower Three Runs about 2.5 miles downstream from the disposal facility (fig. 1).

The U.S. Geological Survey (USGS) initiated an investigation in 2007 to evaluate the potential for tritium uptake by riparian trees in the vicinity of Mary's Branch Creek, thereby decreasing the amount of tritium discharging to the creek. Groundwater, surface water, water extracted from tree cores, whole tree cores, and water condensed from air were analyzed for tritium concentration. The purpose of this report is to present and discuss tritium data from these environmental samples and transpiration data from trees near Mary's Branch Creek, Barnwell, South Carolina. 

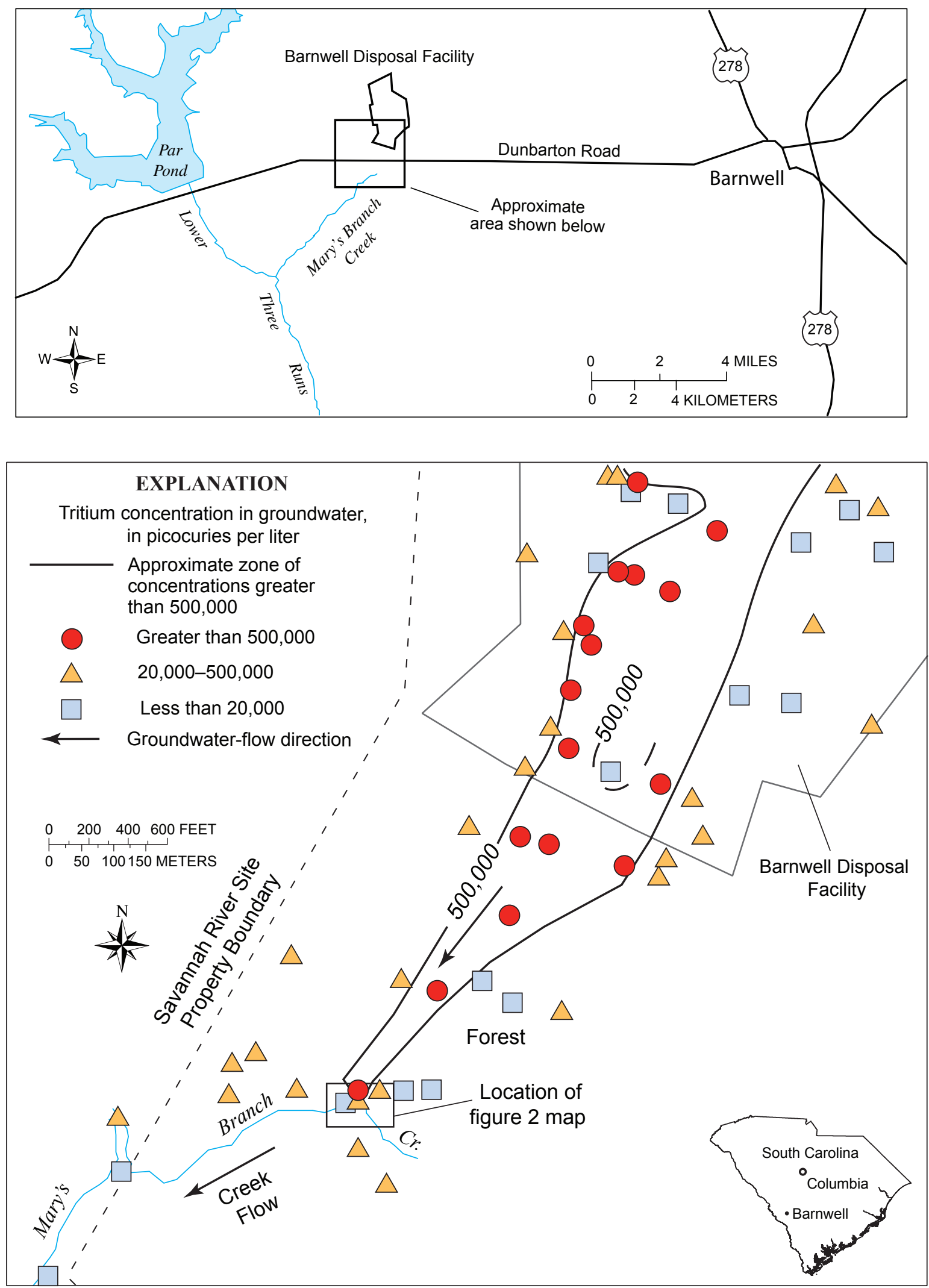

Figure 1. Location of Barnwell Disposal Facility and concentrations of tritium in groundwater (modified from Energy Solutions, 2007), Barnwell, South Carolina. 


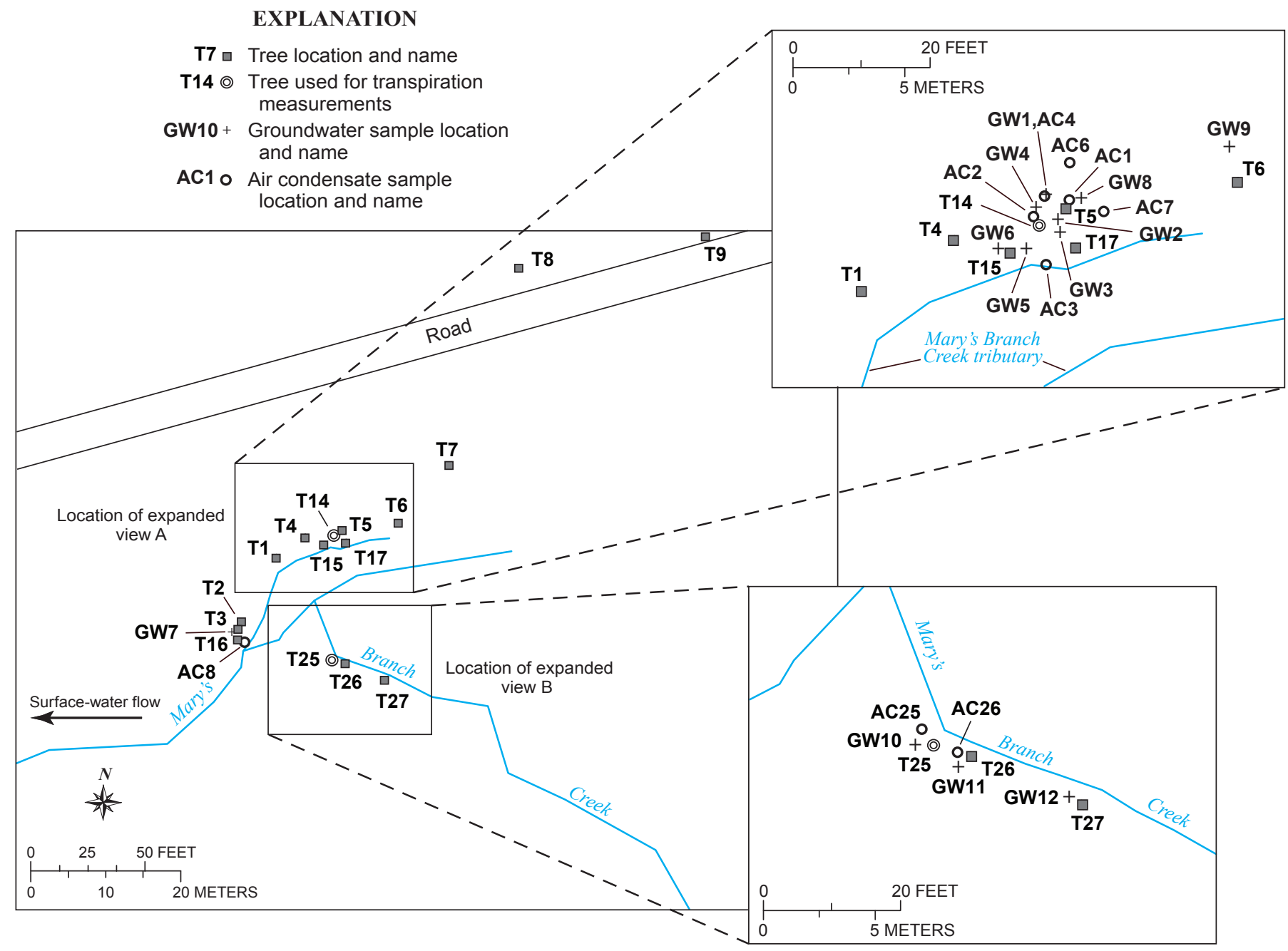

Figure 2. Sampling locations near Mary's Branch Creek, Barnwell, South Carolina, 2007-2009.

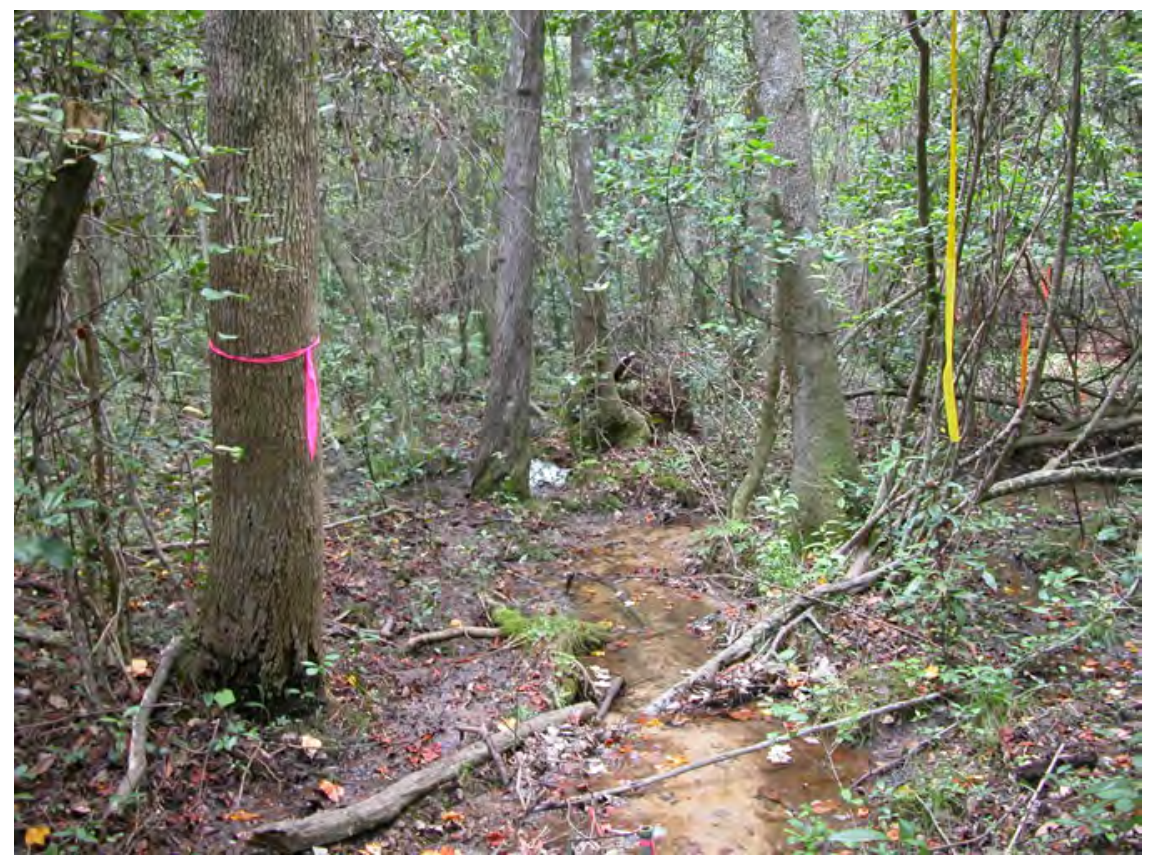

Figure 3. Mary's Branch Creek showing tree T27 (tied with pink ribbon), looking northwest, Barnwell, South Carolina, June 29, 2009. 


\section{Methods}

During this investigation, tritium concentrations were obtained from a variety of environmental samples. The samples included shallow groundwater, surface water, water extracted from tree cores, whole tree cores, and water condensed from air.

For this investigation, 27 trees of varying species were examined for tritium concentration (table 1). Water was extracted and analyzed for tritium content from 47 tree cores, representing 16 total trees, 9 of which were adjacent to Mary's Branch Creek. Forty-two whole tree cores were analyzed for tritium, representing 19 trees, 13 of which were near Mary's Branch Creek. Eighteen samples of groundwater and
24 samples of water condensed from air were analyzed for tritium. Transpiration data were collected from tree T14 in 2008 and from tree T25 in 2009 (fig. 2).

Background sample locations are beyond the area shown in figure 2. Background trees T10-T13 were located within the Mary's Branch Creek drainage basin, but several hundred feet on the opposite side of Mary's Branch Creek from the disposal facility. Background trees T18 and T19 were located about 1,000 ft upstream from the area of known tritiumcontaminated groundwater discharge to Mary's Branch Creek. Background trees T29, T32, and T33 were located within the city limis of Barnwell, several miles from the disposal facility. Background trees T30-T31 were located within the city limits of Columbia, South Carolina, approximately 70 miles northeast of the disposal facility.

Table 1. Trees sampled near Mary's Branch Creek and in background areas, Barnwell, South Carolina, 2007-2009.

\begin{tabular}{|c|c|c|}
\hline $\begin{array}{c}\text { Tree name } \\
\text { (see figure } 2 \text { for location) }\end{array}$ & Species & $\begin{array}{l}\text { Diameter, in inches, at } \\
\text { about } 4 \text { feet above ground }\end{array}$ \\
\hline $\mathrm{T} 1$ & Tulip poplar (Liriodendron tulipifera) & 19 \\
\hline $\mathrm{T} 2$ & Willow oak (Quercus phellos) & 31 \\
\hline $\mathrm{T} 3$ & Holly (Ilex sp.) & 11 \\
\hline $\mathrm{T} 4$ & Oak(Quercus sp.) & 17 \\
\hline T5 & Tulip poplar (Liriodendron tulipifera) & 13 \\
\hline $\mathrm{T} 6$ & Maple (Acer sp.) & 20 \\
\hline $\mathrm{T} 7$ & Sweet gum (Liquidambar sp.) & 9.9 \\
\hline $\mathrm{T} 8$ & Post oak (Quercus stellata) & 13 \\
\hline T9 & Loblolly pine (Pinus taeda) & 21 \\
\hline $\mathrm{T} 10^{*}$ & Willow oak (Quercus phellos) & 11 \\
\hline $\mathrm{T} 11^{*}$ & Sweet gum (Liquidambar sp.) & 10 \\
\hline $\mathrm{T} 12^{*}$ & Post oak (Quercus stellata) & 4.8 \\
\hline T13* & Loblolly pine (Pinus taeda) & 10 \\
\hline $\mathrm{T} 14$ & Sweet gum (Liquidambar sp.) & 15 \\
\hline $\mathrm{T} 15$ & Sweet bay (Laurus nobilis) & 6.7 \\
\hline $\mathrm{T} 16$ & Holly (Ilex sp.) & 6.2 \\
\hline $\mathrm{T} 17$ & Holly (Ilex sp.) & 5.6 \\
\hline $\mathrm{T} 18^{*}$ & Holly (Ilex sp.) & Not measured \\
\hline $\mathrm{T} 19 *$ & Tulip poplar (Liriodendron tulipifera) & Not measured \\
\hline $\mathrm{T} 25$ & Tulip poplar (Liriodendron tulipifera) & 8.9 \\
\hline $\mathrm{T} 26$ & Red maple (Acer rubrum) & 10 \\
\hline $\mathrm{T} 27$ & Tulip poplar (Liriodendron tulipifera) & 14 \\
\hline $\mathrm{T} 29 *$ & Tulip poplar (Liriodendron tulipifera) & $>20$ \\
\hline $\mathrm{T} 30^{*}$ & Red maple (Acer rubrum) & 12 \\
\hline $\mathrm{T} 31^{*}$ & Sweet gum (Liquidambar sp.) & 5.8 \\
\hline $\mathrm{T} 32 *$ & Tulip poplar (Liriodendron tulipifera) & 20 \\
\hline $\mathrm{T} 33 *$ & Red maple (Acer rubrum) & 8.1 \\
\hline
\end{tabular}


Tritium concentrations were determined by using low-level liquid scintillation spectroscopy (Tri-Carb Liquid Scintillation Analyzer Model 1600TR ${ }^{\mathrm{TM}}$, PerkinElmer, Inc.). In brief, aqueous and bulk tissue samples were added without distillation or digestion, respectively, to no more than 10 milliliters $(\mathrm{mL})$ of low-level scintillation cocktail (Ultima Gold $^{\mathrm{TM}}$, PerkinElmer, Inc.) in $20 \mathrm{~mL}$ plastic counting vials and capped. The sample disintegrations per minute (DPM) were analyzed using the Direct DPM option of the Model 1600 TR $^{\text {TM }}$ (Cook and others, 1992). Samples were analyzed at either the USGS laboratory in Columbia, SC, or GEL Laboratories LLC in Charleston, SC. Quality control included collection of duplicate samples. In some cases, both the original and duplicate were analyzed at the USGS laboratory. In other cases, the original was analyzed at the USGS laboratory, and the duplicate was analyzed at GEL Laboratories LLC. Data analyzed by the USGS laboratory in 2007-2009 used a 10-minute counting time. Data analyzed by the USGS laboratory in 2009 used a 1-minute counting time, with the exception of the surface-water sample, groundwater sample G12, and tree core-water samples T25-East, T26-West, and T27-West, which were analyzed using a 10-minute counting time. Samples analyzed by GEL Laboratories LLC used a 15-minute count time. In general, increased counting times produce decreased measurement error.

Groundwater samples were obtained by inserting a pushpoint sampler $1.5 \mathrm{ft}$ or less into the soil and using a peristaltic pump to collect groundwater. Samples were collected in $40-\mathrm{mL}$ volatile organic analysis vials. Duplicate samples were collected and analyzed in October 2008 and both the original and duplicate contained undetectable tritium at a samplespecific reporting limit of $500 \mathrm{pCi} / \mathrm{L}$.

The single surface-water sample collected from Mary's Branch Creek was obtained by pumping from beneath the water surface by means of tubing attached to a peristaltic pump. The sample was collected at 12:23 p.m. on September 9, 2009, from Mary's Branch Creek adjacent to tree T25, which is adjacent to the creek (fig. 2).

Tree-core samples were obtained by use of a 0.2 -inchdiameter increment borer. In most cases, cores were collected from multiple sides of the trees because of the potential for differences in contaminant concentrations on different sides of the tree (Vroblesky, 2008). Water was extracted from the tree cores by placing the tree cores in $40-\mathrm{mL}$ vials and microwaving them for 90 seconds (fig. 4). The vials were then allowed to cool and condense the extracted water vapor on the sides and bottom of the vial. Approximately $0.3 \mathrm{~mL}$ of water typically was obtained per 3 -inch-long tree core by using this method. A similar approach was used by Kalisz and others (1988) in which water was extracted from foliage by using a microwave oven, and the condensate was analyzed for tritium content. The July 2008 values cited in this report for tree-core water are listed as approximate concentrations because a uniform value of $0.33 \mathrm{~mL}$ was used to represent the sample volume for the data collected on July 16, 2008. The uniform value was used because of uncertainties in the measurements of July 2008 sample volumes. This uniform value $(0.33 \mathrm{~mL})$ is based on the measurement of the water volume extracted from tree T5 in October 2008 as well as from several trees in the study area and background areas sampled in 2009 . The volume of water collected from tree core T5 in October 2008 was $0.3 \mathrm{~mL}$. The average volumes of water collected from 7 tree cores on June 9, 2009, 2 tree cores on June 10, 2009, and 13 tree cores on June 29, 2009, was $0.33 \mathrm{~mL}$, with a standard deviation of 0.14 . Based on the range of water volumes extracted from tree cores in October 2008 and June 2009, the average error in tritium calculations associated with using a uniform value to represent sample volume for the July 2008 data is probably about \pm 35 percent. Analysis of tritium in water extracted from tree cores resulted in a relatively high quantitation limit $(16,000 \mathrm{pCi} / \mathrm{L})$, primarily because of the result of large dilution factors and small sample volumes.

Analysis of whole tree-core samples for tritium involved placing each core in a scintillation cocktail and analyzing the whole core. With this approach, the only tritium detections are those on the outer surface of the tree core. This value, therefore, does not represent the entire mass of the tree core. Because the resulting value does not reflect picocuries per liter or picocuries per gram of wood, data from the analysis of whole tree cores are herein reported as disintegrations per minute per tree core (DPM/tree core). In 2007, tree cores were analyzed without prior drying. In 2008, the tree cores were

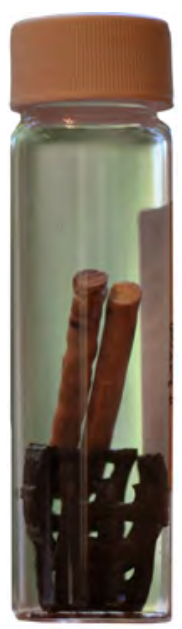

Figure 4. Vial (40-milliliter volume) containing tree core and plastic screen to isolate wood from extracted water. 
analyzed after removing most of the water by using a microwave oven in order to analyze the water separately. Removal of the water likely resulted in lower whole tree-core tritium concentrations than would have been present if the sample had been analyzed without removal of the water, but no specific comparisons were done to make that determination.

To obtain tritium concentrations in the air, water was condensed from the air and analyzed for tritium content. The water was condensed from the air by use of frozen water bottles suspended in the air with a funnel attached to the bottom of the bottle and a 40-mL vial attached to the bottom of the funnel (fig. 5). To obtain samples from various heights up the trees, condensing samplers were attached to a $37-\mathrm{ft}$ expandable pole. Typically, about $15-20 \mathrm{~mL}$ of water was condensed from the air over a few hours by this method. Previous investigations have used condensed water from the air to examine tritium concentrations in soil water vapor by passing soil vapor through a freeze trap (Andraski and others, 2003; 2005). Background samples AC10, AC11, and AC28 were obtained in Columbia, SC. Background sample AC9 was obtained from a location approximately $200 \mathrm{ft}$ west of the map area shown in figure 2 and probably is west of the groundwater contamination plume.

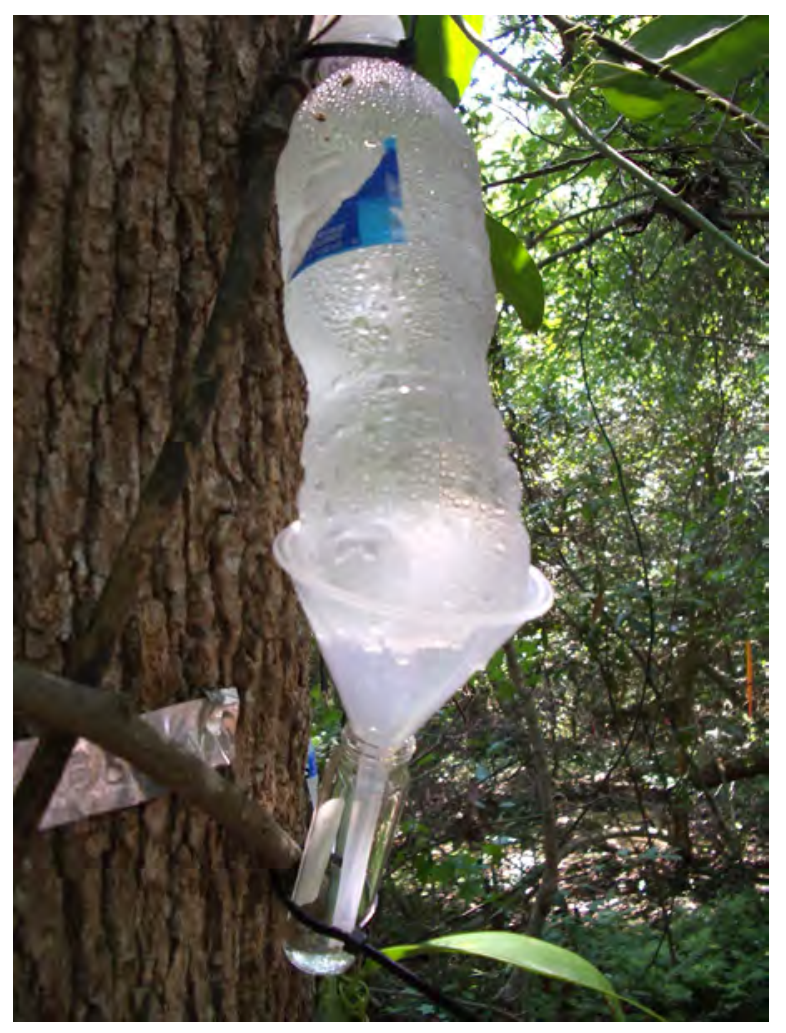

Figure 5. Frozen water bottle, funnel, and 40-milliliter vial in the process of condensing water from forest air near Mary's Branch Creek, Barnwell, South Carolina, June 8, 2009.
Adjustment of the tritium concentration in water condensed from the air, in picocuries per liter of water $\left(C_{W}\right)$, to concentrations of tritium in picocuries per liter of air $\left(C_{A}\right)$ was done by using the following equation:

$$
C_{A}=A H \times \frac{C_{W}}{1,000}
$$

Where $A H$ is the absolute humidity, in liters (or kilograms), of water contained in a cubic meter of air. Equations used to calculate the $A H$ are as follows (provided by Dr. Greg Carbone, Climatology Professor, Department of Geography, University of South Carolina, written commun., 2008):

$$
A H=1,000 \times \frac{A V P}{461 \times T}
$$

Where $T$ is the temperature in degrees Kelvin, and $A V P$ is the absolute vapor pressure, in kilograms per cubic meter, as defined by the following equation:

$$
A V P=S V P \times \frac{R H}{100},
$$

Where $R H$ is the percent relative humidity, and SVP is the saturation vapor pressure, in kilopascals, as defined by the following equation:

$$
S V P=0.611 \times e^{\left(5,423 \times \frac{1}{273}-\frac{1}{T}\right)}
$$

The temperature and relative humidity were measured near Mary's Branch Creek by use of a digital sling psychrometer held at approximately chest height. The temperature and relative humidity measured during sampling events ranged from 83 to 89 degrees Celsius and 46 to 65 percent, respectively. There was little or no air circulation at chest height during the sampling events.

Sap-flow velocity was measured on October 1 and 2, 2008 , and June 5, 2009, on representative trees using a modified method of Granier (1987) by attaching two, 1.18-inchlong thermal dissipation probes (TDPTM, Dynamax, Inc.) into the tree stemwood. Sap-flow measurements concentrate on the outer part of the trunk because it is the zone of greatest water flow during transpiration. In ring-porous trees, over 90 percent of water transported through the xylem is in the outermost growth ring (Ellmore and Ewers, 1986). The transpiration rate was calculated by multiplying the measured sap-flow velocity by the stemwood area as determined from tree cores. The transpiration rate for June 5, 2009, should be considered a minimum probable value because no data were collected prior to noon that day. 


\section{Tritium Concentrations in Environmental Samples}

Groundwater samples collected from the vicinity of Mary's Branch Creek show a broad range of tritium concentrations (less than 500 to $1,490,000 \mathrm{pCi} / \mathrm{L}$; table 2). Such variation is not surprising because of the shallow depth of the samples ( 0.7 to $1.5 \mathrm{ft}$ below land surface [BLS]). The tritiumcontaminated groundwater near the creek may be overlain by a zone of uncontaminated groundwater that discharges to the creek; therefore, parts of the shallow groundwater beneath the creek may represent discharging uncontaminated groundwater, tritium-contaminated groundwater, local infiltration of rainwater, or a mixture. The single surface-water sample collected from Mary's Branch Creek contained 107,000 pCi/L of tritium (table 2).

Water extracted from at least one of the cores from each of the nine trees sampled in the study area near Mary's Branch Creek contained detectable tritium above background concentration (table 3). The tritium concentrations were variable with location, with the side of the tree that was cored, and, in some cases, with the same tree over different dates.
Collection of duplicate cores (within a few centimeters of each other) from the south side of tree T5 on July 16, 2008, showed little difference in tritium concentration in the water extracted from the two cores $(51,800$ and $54,600 \mathrm{pCi} / \mathrm{L}$; table 3$)$, indicating that the variation probably is not due to collection technique. Concentration variations from the same side of the tree may be related to the source of water to the tree. For example, on June 9, 2009, the west sides of trees T26 and T27 contained core-water tritium concentrations greater than $300,000 \mathrm{pCi} / \mathrm{L}$, yet the east sides contained concentrations less than $16,000 \mathrm{pCi} / \mathrm{L}$ (table 3). The southwestern sides of those trees faced away from Mary's Branch Creek, and the northeastern sides of the trees were within a foot of Mary's Branch Creek. The proximity to different water sources may indicate a difference in concentration uptake as an influence on tritium concentrations from different sides of the trees.

Differences in tritium concentrations in water extracted from the tree cores also were seen in cores taken from the same side of the tree over time (table 3). Tritium concentrations in water extracted from cores taken at the west sides of trees T26 and T27 declined from greater than $300,000 \mathrm{pCi} / \mathrm{L}$ to less than $16,000 \mathrm{pCi} / \mathrm{L}$ from June 9 to June 29, 2009 (table 3). The reason for the decline is not clear. Little or no

Table 2. Concentrations of tritium in groundwater near Mary's Branch Creek and in surface water from Mary's Branch Creek, Barnwell, South Carolina, 2008-2009.

[GW, groundwater sample; $\uparrow$, data analyzed at GEL Laboratories LLC. All other data were analyzed at the U.S. Geological Survey laboratory in Columbia, South Carolina; $<$, less than]

\begin{tabular}{|cccc}
\hline $\begin{array}{c}\text { Sample location } \\
\text { (see figure 2 for location) }\end{array}$ & Collection date & $\begin{array}{c}\text { Depth of sample, in feet } \\
\text { below land surface }\end{array}$ & $\begin{array}{c}\text { Tritium concentration, } \\
\text { in picocuries per liter }\end{array}$ \\
\hline GW1 & $7 / 16 / 2008$ & 1.5 & 3,$720 ; 5,510 \dagger$ \\
\hline GW2 & $7 / 16 / 2008$ & 1.5 & 2,940 \\
\hline GW2 & $9 / 11 / 2008$ & 1 & 1,840 \\
\hline GW3 & $7 / 16 / 2008$ & 1 & 1,840 \\
\hline GW4 & $7 / 16 / 2008$ & 2 & 1,670 \\
\hline GW5 & $7 / 16 / 2008$ & 1 & $591 ; 584 \dagger$ \\
\hline GW6 & $7 / 16 / 2008$ & 1 & 176,$000 ; 204,000 \dagger$ \\
\hline GW7 & $7 / 16 / 2008$ & 1 & $<500$ \\
\hline GW8 & $7 / 16 / 2008$ & 1 & 2,830 \\
\hline GW8 & $10 / 3 / 2008$ & 1 & $<500 ;<500$ \\
\hline GW9 & $7 / 16 / 2008$ & 1 & 2,070 \\
\hline GW10 & $6 / 9 / 2009$ & .7 & $1,370,000 ; 1,410,000 \dagger$ \\
\hline GW10 & $6 / 9 / 2009$ & 1 & $1,490,000$ \\
\hline GW10 & $6 / 29 / 2009$ & 1 & $1,240,000$ \\
\hline GW11 & $6 / 9 / 2009$ & .7 & 438,$000 ; 406,000 \dagger$ \\
\hline GW11 & $6 / 29 / 2009$ & 1 & 161,000 \\
\hline GW12 & $6 / 9 / 2009$ & .7 & 169,$000 ; 179,000 \dagger$ \\
\hline GW12 & $6 / 29 / 2009$ & 1 & 107,000 \\
\hline Surface water ${ }^{1}$ & $6 / 9 / 2009$ & not applicable & \\
\hline
\end{tabular}

${ }^{1}$ The surface-water sample was located adjacent to tree $\mathrm{T} 25$. 
Table 3. Concentrations of tritium in water extracted from tree cores near Mary's Branch Creek, Barnwell, South Carolina, and from background areas, 2008-2009.

$[€$, values are approximate because a uniform value of 0.33 milliliters was used as a representative sample volume; $<$, less than; *, background sample; azimuth direction indicates the side of the tree that was cored]

\begin{tabular}{|c|c|c|}
\hline $\begin{array}{c}\text { Sample location } \\
\text { (see figure } 2 \text { for location) }\end{array}$ & Collection date & $\begin{array}{c}\text { Tritium, } \\
\text { in picocuries } \\
\text { per liter }\end{array}$ \\
\hline T2-South & $7 / 16 / 2008$ & $62,700 €$ \\
\hline T3-East & $7 / 16 / 2008$ & $53,700 €$ \\
\hline T3-North & $7 / 16 / 2008$ & $17,400 €$ \\
\hline T3-South & $7 / 16 / 2008$ & $45,100 €$ \\
\hline T3-West & $7 / 16 / 2008$ & $<16,000 €$ \\
\hline T5-East & $7 / 16 / 2008$ & $33,000 €$ \\
\hline T5-North & $7 / 16 / 2008$ & $25,300 €$ \\
\hline T5-South & $7 / 16 / 2008$ & $51,800 €$ \\
\hline T5-South & $7 / 16 / 2008$ & $54,600 €$ \\
\hline T5-West & $7 / 16 / 2008$ & $63,700 €$ \\
\hline T5-West & $10 / 3 / 2008$ & $<16,000$ \\
\hline T14-East & $7 / 16 / 2008$ & $41,100 €$ \\
\hline T14-North & $7 / 16 / 2008$ & $<16,000 €$ \\
\hline T14-South & $7 / 16 / 2008$ & $53,000 €$ \\
\hline T14-West & $7 / 16 / 2008$ & $<16,000 €$ \\
\hline T14-West & 6/9/2009 & $<16,000$ \\
\hline T16-East & $7 / 16 / 2008$ & $49,400 €$ \\
\hline T16-North & $7 / 16 / 2008$ & $48,300 €$ \\
\hline T16-West & $7 / 16 / 2008$ & $38,000 €$ \\
\hline T17-East & $7 / 16 / 2008$ & $<16,000 €$ \\
\hline T17-North & $7 / 16 / 2008$ & $54,500 €$ \\
\hline T17-South & $7 / 16 / 2008$ & $<16,000 €$ \\
\hline T17-West & $7 / 16 / 2008$ & $22,900 €$ \\
\hline T18-North* & $7 / 16 / 2008$ & $<16,000 €$ \\
\hline T18-South* & $7 / 16 / 2008$ & $<16,000 €$ \\
\hline T19-North* & $7 / 16 / 2008$ & $<16,000 €$ \\
\hline T25-East & $6 / 29 / 2009$ & 655,000 \\
\hline T25-North & $6 / 29 / 2009$ & 372,000 \\
\hline T25-South & $6 / 29 / 2009$ & 650,000 \\
\hline T25-West & $6 / 9 / 2009$ & 693,000 \\
\hline T26-East & $6 / 9 / 2009$ & $<16,000$ \\
\hline T26-East & $6 / 29 / 2009$ & $<16,000$ \\
\hline T26-West & $6 / 9 / 2009$ & 327,000 \\
\hline T26-West & $6 / 29 / 2009$ & $<16,000$ \\
\hline T26-South & $6 / 29 / 2009$ & $<16,000$ \\
\hline T26-North & $6 / 29 / 2009$ & $<16,000$ \\
\hline T27-East & $6 / 9 / 2009$ & $<16,000$ \\
\hline T27-East & $6 / 29 / 2009$ & $<16,000$ \\
\hline T27-West & $6 / 9 / 2009$ & 819,000 \\
\hline T27-West & $6 / 29 / 2009$ & $<16,000$ \\
\hline T27-South & $6 / 29 / 2009$ & $<16,000$ \\
\hline T27-North & $6 / 29 / 2009$ & $<16,000$ \\
\hline T29-West* & 6/9/2009 & $<16,000$ \\
\hline T30-South* & $6 / 10 / 2009$ & $<16,000$ \\
\hline T31-West* & $6 / 10 / 2009$ & $<16,000$ \\
\hline T32-North* & $6 / 29 / 2009$ & $<16,000$ \\
\hline T33-North* & $6 / 29 / 2009$ & $<16,000$ \\
\hline
\end{tabular}

rainfall took place in Barnwell during the 10 days prior to the June 29 sampling, so rainfall dilution of the tritium was not a factor. Although a substantial decrease in groundwater tritium concentration was seen adjacent to tree T26 from June 9 to June 29 (site G11), no substantial change in groundwater tritium concentrations was seen adjacent to tree T27 (site G12; table 2). One possible explanation is that in the heterogeneous environment near Mary's Branch Creek, the limited number of samples collected during this investigation were too few to fully characterize the spatial and temporal influences on tritium concentrations in groundwater and tree samples, although the differences may be due to other environmental factors not yet identified.

Analysis of tree cores showed that the cores from most of the trees near Mary's Branch Creek contained tritium at concentrations greater than those found in background trees (table 4). The highest concentrations in cores collected on July 16, 2008, were in trees T5 and T14, which are located adjacent to each other (table 4; fig. 2). Cores from some trees in the study area contained no detectable tritium, such as trees T6 and T7, which are thought to be east of the groundwater tritium plume, and trees T8 and T9, which are up a steep embankment with probably little direct root contact with tritium-contaminated groundwater (table 4). For unknown reasons, the single core from tree $\mathrm{T} 4$ contained no detectable tritium despite the fact that it was near other trees that did contain tritium.

The presence of tritium in tree cores and in water extracted from tree cores in areas where the roots come into contact with tritium-contaminated groundwater indicates that groundwater contaminated by tritium is being taken up by the trees during transpiration. These data also indicate that collection and analysis of tree cores and water extracted from tree cores have the potential to be used as a tool for location of shallow tritium-contaminated groundwater; phytoremediation may be a viable tool to assist in remediation of tritium contamination in this groundwater discharge area.

Air condensate samples collected from near Mary's Branch Creek showed higher-than-background tritium concentrations. Tritium concentrations in water condensed from air near the creek contained 1,300 to $67,000 \mathrm{pCi} / \mathrm{L}$, while concentrations in water condensed from air in background areas was less than $800 \mathrm{pCi} / \mathrm{L}$ (table 5). The maximum concentrations, when converted to concentrations in air, were less than $15 \mathrm{pCi} / \mathrm{L}$ of air. In most cases, the tritium concentrations in air were less than $5 \mathrm{pCi} / \mathrm{L}$ of air. The maximum allowable effluent concentration of tritium in air is $100 \mathrm{pCi} / \mathrm{L}$ (South Carolina Department of Health and Environmental Control, 2007). Therefore, the detected tritium concentrations in air were substantially lower than concentrations considered to be hazardous to human health.

In July and October 2008, concentrations of tritium in water condensed from the air were generally greater near the ground than in the tree canopy at heights greater than $12 \mathrm{ft}$. This finding may be a function of a larger amount of tritium evaporation near the ground than in the tree canopy, or it 
Table 4. Concentrations of tritium in whole tree cores near Mary's Branch Creek, Barnwell, South Carolina, and from background areas, 2007-2008.

$[<$, less than; *, background tree; azimuth direction, where noted, indicates the side of the tree from which the sample was obtained]

\begin{tabular}{|c|c|c|}
\hline $\begin{array}{c}\text { Sample location } \\
\text { (see figure } 2 \text { for location) }\end{array}$ & Collection date & $\begin{array}{c}\text { Tritium, } \\
\text { in disintegrations } \\
\text { per minute per } \\
\text { tree core }\end{array}$ \\
\hline T1-North & $10 / 2 / 2007$ & 59 \\
\hline T1-South & $10 / 2 / 2007$ & 56 \\
\hline T2-North & $10 / 2 / 2007$ & $<30$ \\
\hline T2-North & $10 / 2 / 2007$ & $<30$ \\
\hline T2-South & $7 / 16 / 2008$ & 110 \\
\hline T3-North & $10 / 2 / 2007$ & $<30$ \\
\hline T3-South & $10 / 2 / 2007$ & $<30$ \\
\hline T3-East & $7 / 16 / 2008$ & 73 \\
\hline T3-North & $7 / 16 / 2008$ & $<30$ \\
\hline T3-South & $7 / 16 / 2008$ & $<30$ \\
\hline T3-West & $7 / 16 / 2008$ & $<30$ \\
\hline T4-North & $10 / 2 / 2007$ & $<10$ \\
\hline T5-North & $10 / 2 / 2007$ & 32 \\
\hline T5-East & $7 / 16 / 2008$ & 88 \\
\hline T5-North & $7 / 16 / 2008$ & 57 \\
\hline T5-South & $7 / 16 / 2008$ & 191 \\
\hline T5-South & $7 / 16 / 2008$ & 170 \\
\hline T5-West & $7 / 16 / 2008$ & 186 \\
\hline T5-West & $10 / 3 / 2008$ & 36 \\
\hline T6-North & $10 / 2 / 2007$ & $<30$ \\
\hline T7-North & $10 / 2 / 2007$ & $<30$ \\
\hline T8-North & $10 / 2 / 2007$ & $<30$ \\
\hline T9-North & $10 / 2 / 2007$ & $<30$ \\
\hline $\mathrm{T} 10^{*}$ & $10 / 2 / 2007$ & $<30$ \\
\hline $\mathrm{T} 11^{*}$ & $10 / 2 / 2007$ & $<30$ \\
\hline T12* & $10 / 2 / 2007$ & $<30$ \\
\hline $\mathrm{T} 13 *$ & $10 / 2 / 2007$ & $<30$ \\
\hline T14-East & $7 / 16 / 2008$ & 110 \\
\hline T14-North & $7 / 16 / 2008$ & 47 \\
\hline T14-South & $7 / 16 / 2008$ & 220 \\
\hline T14-West & $7 / 16 / 2008$ & 97 \\
\hline T15-West & $9 / 11 / 2008$ & 36 \\
\hline T16-North & $7 / 16 / 2008$ & 56 \\
\hline T16-West & $7 / 16 / 2008$ & 75 \\
\hline T17-East & $7 / 16 / 2008$ & 42 \\
\hline T17-North & $7 / 16 / 2008$ & 63 \\
\hline T17-South & $7 / 16 / 2008$ & 33 \\
\hline T17-West & $7 / 16 / 2008$ & 40 \\
\hline T18-North* & $7 / 16 / 2008$ & $<30$ \\
\hline T18-South* & $7 / 16 / 2008$ & $<30$ \\
\hline T19-North* & $7 / 16 / 2008$ & $<30$ \\
\hline T19-South* & $7 / 16 / 2008$ & $<30$ \\
\hline
\end{tabular}


Table 5. Concentrations of tritium in water condensed from air and concentrations of tritium in air near Mary's Branch Creek, Barnwell, South Carolina, and from background areas, 2008-2009.

$[*$, background sample; $<$, less than; $\dagger$, data analyzed at GEL Laboratories LLC. All other data were analyzed at the U.S.Geological Survey laboratory in Columbia, SC]

\begin{tabular}{|c|c|c|c|c|}
\hline $\begin{array}{l}\text { Sample location } \\
\text { (see figure } 2 \text { for location) }\end{array}$ & $\begin{array}{l}\text { Sample height } \\
\text { above ground, } \\
\text { in feet }\end{array}$ & Collection date & $\begin{array}{l}\text { Tritium concentration } \\
\text { in water condensed } \\
\text { from air, in picocuries } \\
\text { per liter of water }\end{array}$ & $\begin{array}{l}\text { Calculated tritium } \\
\text { concentration } \\
\text { in air, in picocuries } \\
\text { per liter of air }\end{array}$ \\
\hline $\mathrm{ACl}$ & 0.5 & $7 / 16 / 2008$ & 21,$100 ; 32,400 \dagger$ & $4.2 ; 6.5$ \\
\hline $\mathrm{AC} 1$ & 5 & $7 / 16 / 2008$ & 13,000 & 2.6 \\
\hline $\mathrm{AC} 1$ & 12.5 & $7 / 16 / 2008$ & 4,200 & 0.8 \\
\hline $\mathrm{AC} 1$ & .5 & $10 / 3 / 2008$ & 23,400 & 4.7 \\
\hline $\mathrm{AC} 1$ & 6 & $10 / 3 / 2008$ & 10,700 & 2.1 \\
\hline $\mathrm{AC} 1$ & 24 & $10 / 3 / 2008$ & 3,610 & 0.7 \\
\hline $\mathrm{AC} 1$ & 38 & $10 / 3 / 2008$ & 2,420 & 0.5 \\
\hline $\mathrm{AC} 2$ & 4.5 & $7 / 16 / 2008$ & 19,$000 ; 22,000$ & $3.8 ; 4.4$ \\
\hline $\mathrm{AC} 3$ & 1 & $7 / 16 / 2008$ & 37,$400 ; 67,000 \dagger$ & $7.5,13.5$ \\
\hline $\mathrm{AC} 4$ & 0 & $7 / 16 / 2008$ & 19,700 & 4.0 \\
\hline $\mathrm{AC} 5$ & .5 & $7 / 16 / 2008$ & 15,200 & 3.1 \\
\hline AC6 & .5 & $7 / 16 / 2008$ & 1,300 & 1.5 \\
\hline $\mathrm{AC7}$ & 6 & $7 / 16 / 2008$ & 9,620 & 1.9 \\
\hline $\mathrm{AC} 8$ & 6 & $7 / 16 / 2008$ & 8,360 & 1.7 \\
\hline $\mathrm{AC} 9^{*}$ & .5 & $7 / 16 / 2008$ & $<800$ & $<0.2$ \\
\hline $\mathrm{AC} 10^{*}$ & .5 & $7 / 25 / 2008$ & $<800$ & $<0.2$ \\
\hline $\mathrm{AC} 10^{*}$ & .5 & $10 / 4 / 2008$ & $<800$ & $<0.2$ \\
\hline $\mathrm{AC} 25$ & 34 & $6 / 9 / 2009$ & $9,740 \dagger$ & 2.5 \\
\hline $\mathrm{AC} 25$ & 3 & $6 / 9 / 2009$ & $7,190 \dagger$ & 2.2 \\
\hline AC28* & .5 & $6 / 10 / 2009$ & $<154 \dagger$ & $<0.2$ \\
\hline AC26 & 37 & $6 / 29 / 2009$ & $6,940 \dagger$ & 1.9 \\
\hline AC26 & 24 & $6 / 29 / 2009$ & $4,900 \dagger$ & 1.0 \\
\hline $\mathrm{AC} 26$ & 19 & $6 / 29 / 2009$ & $4,070 \dagger$ & 0.9 \\
\hline
\end{tabular}

Table 6. Transpiration rates measured in trees at Mary's Branch Creek, Barnwell, South Carolina, 2008-2009.

\begin{tabular}{ccc}
\hline $\begin{array}{c}\text { Tree name } \\
\text { (see figure 2 for location) }\end{array}$ & Date & $\begin{array}{c}\text { Transpired water, } \\
\text { in liters per day }\end{array}$ \\
\hline T14 & $10 / 1 / 2008$ & 9.9 \\
T14 & $10 / 2 / 2008$ & 12.4 \\
T25 & $6 / 5 / 2009$ & At least $24.4^{1}$ \\
\hline
\end{tabular}

\footnotetext{
${ }^{1}$ The actual value is probably higher than shown because pre-noon data were not collected.
} 


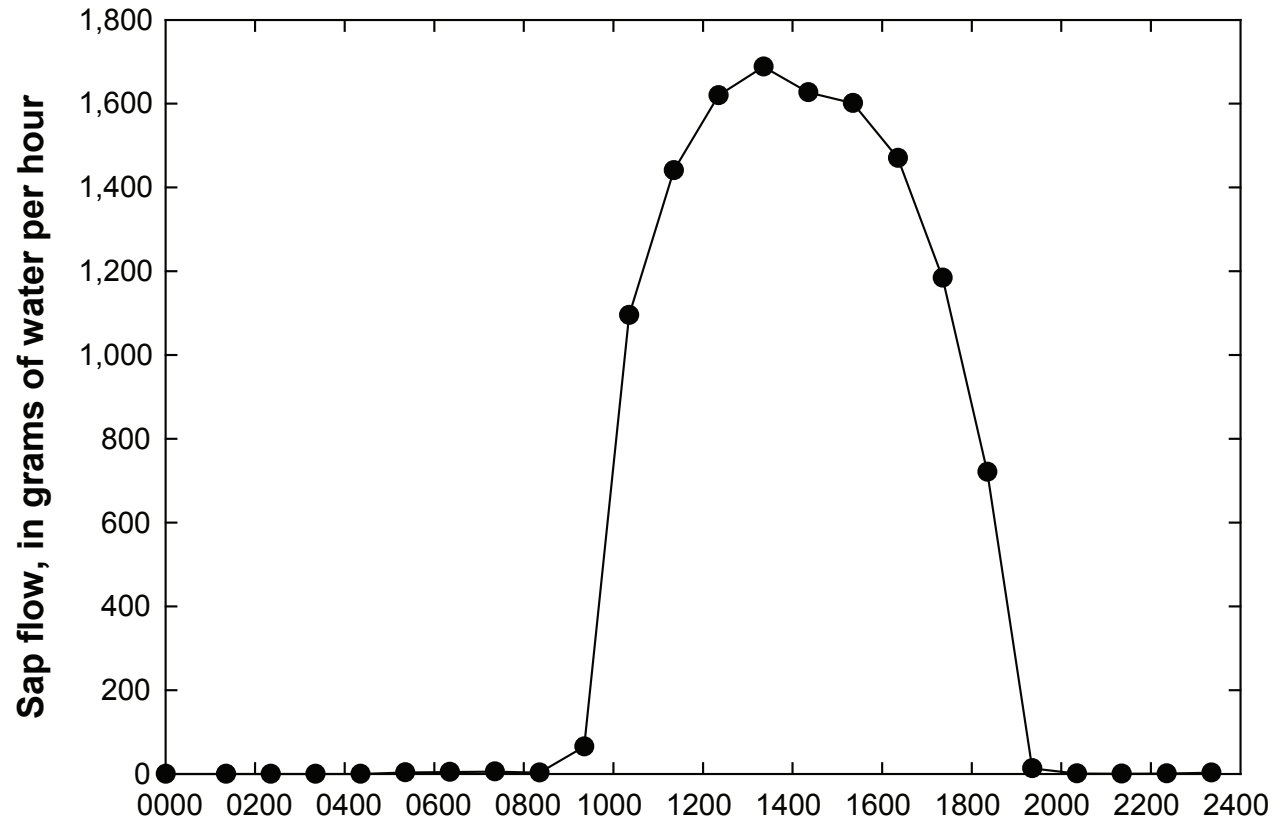

Time of day (military time)
Figure 6. Sap-flow measurements from tree T14, October 2, 2008, near Mary's Branch Creek, Barnwell, South Carolina.

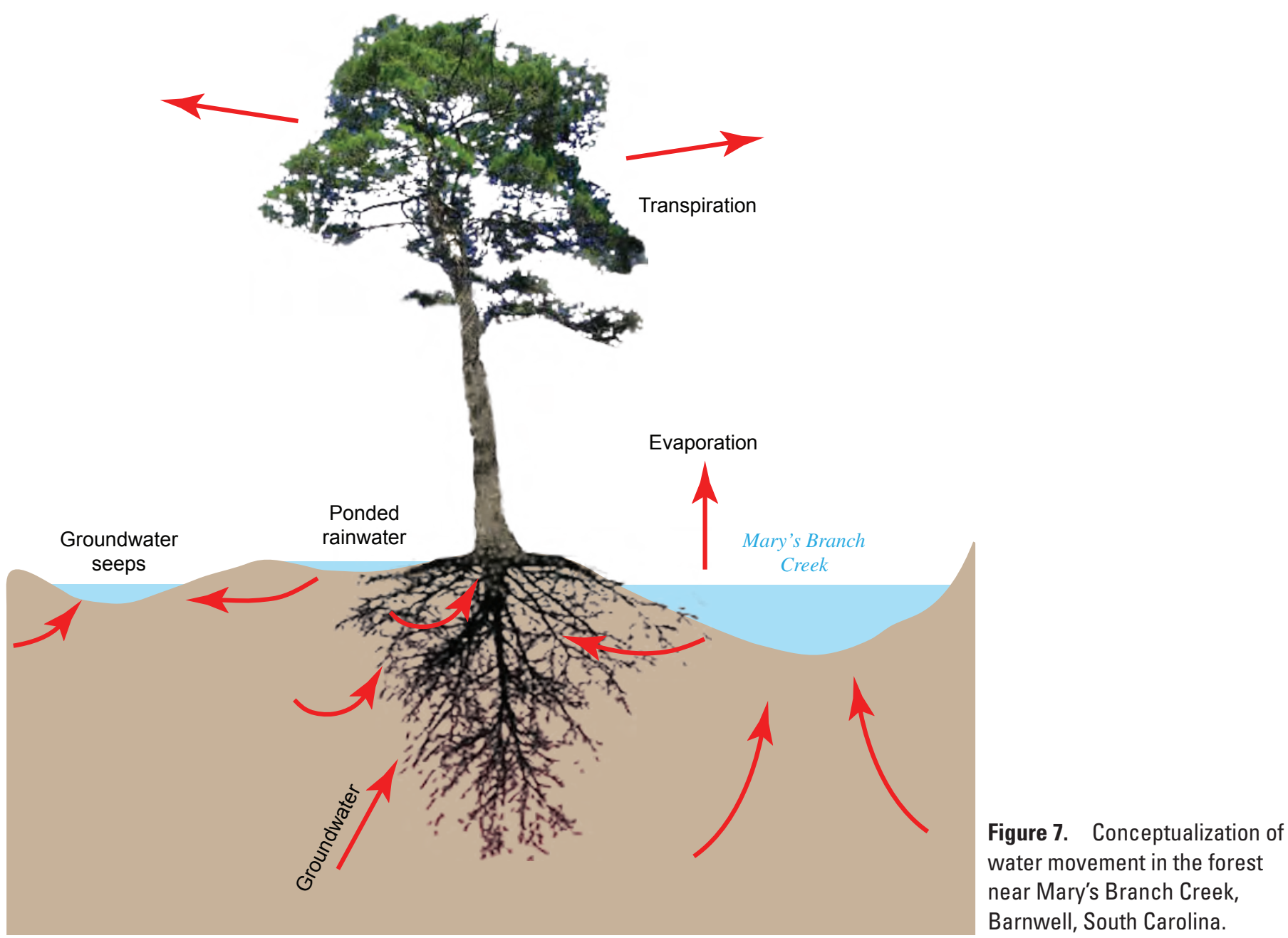


The presence of tritium in the forest air probably is a result of evaporation from soil and surface water and uptake of tritium-contaminated groundwater by the trees and transpiration of the tritium into the air from the leaves. The low concentrations of tritium detected in air indicate that although tritium-contaminated groundwater is removed from the shallow subsurface and released to the atmosphere by these processes, there is no evidence that the attenuation resulted in a vapor hazard in the forest.

\section{Summary}

Tritium from a low-level radioactive waste disposal facility is present in groundwater near Barnwell, South Carolina. The tritium-contaminated groundwater discharges to Mary's Branch Creek, approximately 3,000 ft south of the disposal facility. This investigation examined the potential for tritium uptake by riparian trees in the vicinity of Mary's Branch Creek to reduce the amount of tritium discharging to the creek. Groundwater, surface water, water extracted from tree cores, whole tree cores in the riparian zone, and water condensed from air were analyzed for tritium content. Water extracted from one or more of the cores from each of nine trees sampled in the study area near Mary's Branch Creek contained detectable tritium above background concentration. Tritium was not found in water extracted from tree cores from background trees, from trees on a hill where it was unlikely that the roots were in contact with contaminated groundwater, or from trees considered to be to the east of the groundwater contamination. Tritium was present at greater-than-background concentrations in water extracted from air in the vicinity of Mary's Branch Creek, but the concentrations were lower than concentrations considered by the State of South Carolina to be hazardous to human health. The presence of tritium in the trees indicates that the trees are taking up tritium-contaminated groundwater during transpiration. Therefore, analysis of tree material has the potential to be a useful tool in identifying shallow tritiumcontaminated groundwater. Based on the transpiration rate of tree T25 on June 5, 2009, and the presence of $1,410,000 \mathrm{pCi} / \mathrm{L}$ in groundwater adjacent to tree T25 on June 9, 2009, it is likely that tree T25 probably transpires more than 17.1 million $\mathrm{pCi} /$ day in the summer, with lower concentrations during the winter. Because this calculation represents only a single tree, and because contaminant concentrations vary across the study area, the calculated tritium transpiration value should not be uniformly applied across the site. Lower groundwater tritium concentrations were found on the north side of Mary's Branch Creek than near tree T25, so tritium transpiration rates probably are lower along the north side of Mary's Branch Creek than near tree T25. The data show that the trees remove a portion of the tritium-contaminated groundwater, thus reducing the amount of tritium discharge to Mary's Branch Creek. No evidence was found that removal of tritium-contaminated groundwater by soil evaporation, root uptake and discharge of tritium by transpiration at the leaves created a vapor hazard in the forest.

\section{Acknowledgments}

Special thanks are due to Vernon Ichimura from Energy Solutions and his associates for their help during field activities and for their useful reviews of the manuscript. Thanks also are due to Dr. Greg Carbone, Climatology Professor at the University of South Carolina, for his help in providing formulas to relate temperature and relative humidity to absolute humidity.

\section{References Cited}

Andraski, B.J., Sandstrom, M.W., Michel, R.L., Radyk, J.C., Stonestrom, D.A., Johnson, M.J., and Mayers, C.J., 2003, Simplified method for detecting tritium contamination in plants and soil: Journal of Environmental Quality, v. 32, p. $988-995$.

Andraski, B.J., Stonestrom, D.A., Michel, R.L., Halford, K.J., and Radyk, J.C., 2005, Plant-based plume-scale mapping of tritium contamination in desert soils: Vadose Zone Journal, v. 4, p. $819-827$.

Cahill, J.M., 1982, Hydrology of the low-level radioactivesolid-waste burial site and vicinity near Barnwell, South Carolina: U.S. Geological Survey Open-File Report 82-863, $101 \mathrm{p}$.

Cook, G.T., Scott, E.M., Wright, E.M., and Anderson, R., 1992, The statistics of low-level counting using the new generation of Packard liquid scintillation counters: Radiocarbon, v. 34 , no. 4 , p. 360-365.

Ellmore, G.S., and Ewers, F.W., 1986, Fluid flow in the outermost xylem increment of a ring-porous tree, Ulmus Americana: American Journal of Botany, v. 73, no. 12, p. 1771-1774.

Energy Solutions, 2007, Tritium migration status for the Barnwell Radioactive Waste Disposal Facility, September 2007: Consultant's report to South Carolina Department of Health and Environmental Control, Report BEDL-07-037, 24 p.

Granier, A., 1987, Evaluation of transpiration in a Douglas fir stand by means of sap flow measurements: Tree Physiology, v. 3, p. 309-320.

Kalisz, P.J., Stringer, J.W., Volpe, J.A., and Clark, D.T., 1988, Trees as monitors of tritium in soil water: Journal of Environmental Quality, v. 17, no. 1, p. 62-70.

South Carolina Department of Health and Environmental Control, 2007, Radiological Health, Regulation R6163.A.RHA.3.53, Part III, Appendix B, Table 2, Column 1, accessed in September 2009 at http://www.scdhec.gov/ health/radhlth/61-63.htm.

Vroblesky, D.A., 2008, User's guide to the collection and analysis of tree cores to assess the distribution of subsurface volatile organic compounds: U.S. Geological Survey Scientific Investigations Report 2008-5088, 60 p. 


\section{Prepared by: \\ USGS Enterprise Publishing Network \\ Raleigh Publishing Service Center \\ 3916 Sunset Ridge Road \\ Raleigh, NC 27607}

For additional information regarding this publication, contact: Don A. Vroblesky

USGS South Carolina Water Science Center

720 Gracern Road, Suite 129

Columbia, SC 29210

phone: 1-803-750-6100

email:vroblesk@usgs.gov

Or visit the South Carolina Water Science Center Web site at: http://sc.water.usgs.gov

This publication is available online at: http://pubs.usgs.gov/sir/2009/5245/ 
뜰

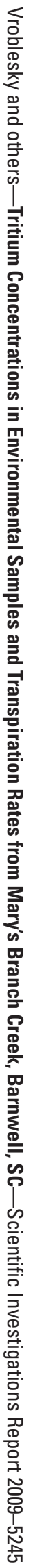

